\title{
READING POVERTY IN MODERNIST LITERATURE: RIFFATERRIAN SEMIOTIC ANALYSIS ON T.S ELIOT'S MORNING AT THE WINDOW
}

\author{
Nestiani Hutami ${ }^{1}$, Diaz Adrian² \\ ${ }^{1}$ English Language Education, UIN Raden Mas Said Surakarta, Surakarta \\ nestiani.hutami@iain-surakarta.ac.id \\ ${ }^{2}$ English Language and Literature, Universitas Airlangga, Surabaya \\ diaz.adrian-2018@fib.unair.ac.id
}

\begin{abstract}
The idea of poverty as the theme has been recurrently used in literature. However, it rarely comes across in Modernist Literature. Accordingly, this study examines poverty as the theme, which is also the main issue in a poem written by T.S. Eliot entitled Morning at the Window. To dive deep into the main issue of the poem, it uses a close-reading method. It focuses on how the text of the poem represents the main issue in which the poem tries to convey. To come into the results of the study, three aspects from Semiotics of Poetry by Michael Riffaterre are used, which are unsustainable expressions, heuristic and hermeneutic reading, and matrix. Analyzing these three aspects, the results show that the representation of poverty as the main issue is evidently stated. The diction in the poem successfully creates the images and sets the tone that correlates with poverty.
\end{abstract}

Keywords: poverty, main issue, poem, semiotics.

\begin{abstract}
Abstrak: Kemiskinan sebagai tema telah sering digunakan dalam kesusastraan. Tetapi, tema ini sangat jarang ada di kesusastraan modern. Dengan demikian, studi ini meneliti kemiskinan sebagai tema, yang juga merupakan isu utama dalam sebuah puisi karya T.S Eliot yang berjudul Morning at the Window. Dalam menganalisis isu utama dalam puisi tersebut, studi ini menggunakan metode close-reading. Analisis ini berfokus pada bagaimana puisi tersebut merepresentasikan isu utama yang berusaha disampaikan. Untuk itu, tiga aspek semiotika puisi Michael Riffaterre, yang terdiri dari ketidaklangsungan ekspresi, pembacaan heuristik dan hermeneutik, dan matriks, digunakan dalam menganalisis. Setelah menganalisis ketiga aspek ini, ditemukan hasil bahwa representasi dari kemiskinan dalam puisi tersebut secara jelas dinyatakan. Diksi dalam puisi tersebut menciptakan penggambaran dan suasana yang berkorelasi dengan kemiskinan
\end{abstract}

Kata Kunci: kemiskinan, isu utama, puisi, semiotika.

\section{INTRODUCTION}

As one of the movements in our time, Modernism plays an essential role in changing the face of literature today. Despite different opinions regarding the precise period of its occurrence, "most scholars generally agree that modernist authors published as early as the 1880s and into the mid-1940s" (Patrick, 2017). During this period, many people were in confusion because of its rapid change. It was an "era characterized by industrialization, the nearly global adoption of capitalism, rapid social change, and advances in science and the social sciences" (Kuiper, 2009). With a good deal of various and impactful events worldwide, the issues brought up in literary texts were diverse and new. Themes like individualism, alienation, absurdity, war, experimentation, and materialism frequently occurred in Modernist Literature. 
Along with those emerging new themes, some writers still used commonly brought up issues in their writing. Though these issues have been recurrently used in literature, they still represent the condition of any period. One of them is poverty. According to United Nations, "poverty entails more than the lack of income and productive resources to ensure sustainable livelihoods. Its manifestations include hunger and malnutrition, limited access to education and other basic services, social discrimination and exclusion, as well as the lack of participation in decision-making" (Ending Poverty, 2021). This definition is in line with what was stated by the European Union (Dvorak, 2015, p. 528); people living in poverty means that they fail to conform with the living standard acceptable in the society they live in. Consequently, they have limited access to fundamental rights, for instance, poor people usually have "a low-paid, irregular, and insecure job," limited access to "clear water and electricity," health care, education, housing, and many others (Gweshengwe \& Hassan, 2020, p. 5). In addition, being poor also affects the mental state because, based on several studies, people living in poverty have lower life satisfaction which leads to a higher level of negative emotion (Bundervoet, 2013; Hanson, 2018; Scutti, 2018; Sharew, 2020; Stokes, 2007).

Building upon poverty's characteristics, one of the Modernist Literature, which is a poem entitled Morning at the Window, is best fit presenting poverty as the main issue. The poem was written by Thomas Stearns Eliot or known as T.S. Eliot, in 1914. It was then published in Eliot's first poetry collection, Prufrock and Other Observations, in 1917. In her article, Julieta Abella (2017) mentions that Morning at the Window depicts a person who looks outside the window and observes the streets. She further analyzes that while observing, the speaker "shows images of poverty" in a modern city and "describes them as everyday scenes. While Abella talks about the images of poverty, a research paper by Mohamed Jabraddar Mahil Abd Allah (2021) mainly examines the depiction of suffering in the poem. He states that "the daily suffering of the poor workers and housemaids" is pointed in the poem. Moreover, he also explains "the depression and sadness" of the people in the poem that their daily lives are "full of disappointment and despair."

Skimming through the text, Morning at the Window does portray despair. It is not the only poem written by Eliot that depicts something dark. Another one is The Waste Land illustrating "the devastation and despair brought on by World War I" (Kim, 2017). As portrayed by both poems, T.S. Eliot wrote about "terrifying isolation, while insisting he was keeping with the oldest traditions of civilization and order" (Howarth, 2012, p. 57). In his essay, "Tradition and the Individual Talent," Eliot also proposes that "a poet must incorporate knowledge of the past and the tradition of poetry of the past in such a way as to reflect awareness of the presence of the past in the present" (Shook, 2005, p. 722). Therefore, it is rather understandable that Eliot wrote poetry by still prioritizing the historical context in something new, such as depicting poverty. 


\section{METHODS}

The paper would like to dive deep into the theme of the poem, which is also the main issue of it. The main issue shown in the poem is poverty. Through the eyes of the speaker, an observer, the readers are given a picture of the conditions of poor people living not far from where he observes them. The people mentioned in the poem look unhappy and seem not to enjoy their lives that much. The depressive atmosphere presented in the story is rooted in the main issue; poverty.

Using Riffaterre's Semiotics of Poetry (1978), the paper focuses on the structure of Eliot's Morning at the Window. The paper will concentrate on the internal aspect of the poem rather than the external aspects such as social and political significance. According to Tyson (2014), a close-reading is an effort to carefully read a text and correlate it to an interpretation of a larger meaning, which would be applied to analyze the text carefully. Riffaterre (1978) proposes that there are three aspects to be examined to fully comprehend how the signs shape the meaning of the poem: Unsustainable expressions; a thorough analysis of the text's language, Heuristic and hermeneutic reading; the first and second stage of interpretation, and Matrix; the basis meaning of the poem.

\section{FINDINGS AND DISCUSSION Illustration}

Looking at the title, Morning at the Window, the readers should easily grasp the time setting of the poem. The speaker is an observer of this poem, observing the people around him dealing with their morning from a window. He sees them, who are most likely servants, rattling their employers' plates in basement kitchens. He then turns his eyes to the street. He sees housemaids looking sad, described by the speaker as "damp souls" that are "sprouting despondently" at area gates.

The waves of brown-colored fog cover the street he is looking at. Through the fog, he sees people going about their morning looking unhappy. He sees a passer-by with muddy skirts, indicating that the street is wet and dirty, crying. A smile comes from her, rather a hopeless one. The fog in this stanza is personified as if it is the one that brings the sadness from the street to the observer on the window.

\section{Unsustainable Expression}

According to Riffaterre (1978, p. 2), Unsustainable expression is caused by three meanings: displaced meaning, distorted meaning, and created meaning. Displacement of meaning in poetry is found through types of figurative language, namely metaphor, metonymy, and personification (1978). Distortion of meaning happens through ambiguity, contradiction, and nonsense (Riffaterre, 1978). Ambiguity allows multiple interpretations to be plausible. Contradiction rises through the use of paradox and irony. And, nonsense is a string of words of which meaning is realized only within the poem. The creation of meaning is realized when the text, acting as an organizing principle, makes sign out of linguistically meaningless grammatical matters (Riffaterre, 1978). It can be seen through enjambement, verse, typography, and homolog. 


\section{Lakon: Jurnal Kajian Sastra dan Budaya}

Volume 10. No. 2, November 2021

The poem starts with a hyperbolic metaphor: "THEY are rattling breakfast plates in basement kitchens,". The observer of the poem uses the word rattling, indicating that the servants are cleaning the dishes rather angrily. In line 3 , the damp souls is used to describe the mental state of the housemaids. Eliot personifies the housemaids' mental state by using damp souls, which in line 4 is described as "sprouting despondently at area gates" indicating the housemaids' worsened mental states. The meaning of the second stanza heavily revolves around the personification of the brown waves of fog. The fog, which also helps set the depressive atmosphere, is personified as if it brings sadness on the street to the speaker. A hyperbolic metaphor is used in "Twisted faces from the bottom of the street," to describe the faces of the people on the street. Another personification is "An aimless smile" and its descriptions; "hovers in the air" and "vanishes along the levels of the roofs"; in the last two lines. Relying heavily on hyperbolic metaphor and personification, the speaker tries to set the tone of how hard it is for poor people to be happy. He uses them to give the readers the images of frustration, depression, sadness, etc. All these images are objective correlatives, which according to Eliot (1921), are a set of events, objects, or situations that evoke a certain emotion of the main issue; poverty.

Paradoxical meaning is created in the very first line of the second stanza: "The brown waves of fog toss up to me". The color brown might indicate that the air in the area presented in the poem is polluted and dirty. However, the color brown can be interpreted differently. Brown, psychologically, might evoke feelings of loneliness, sadness, and emptiness (Cherry, 2020), which resonate throughout the poem. "An aimless smile" is also paradoxical, whether it is from the same person with muddy skirts or from a totally different person.

Enjambement is a leap from line to line. Sayuti stated that it is used to convey thought in an articulate manner (1985). In both stanzas of Morning at the Window, there are three enjambments.

\section{And along the trampled edges of the street I am aware of the damp souls of housemaids Sprouting despondently at area gates.}

The whole of the first stanza is a compound sentence if the first line is inserted. However, with the use of coordinating conjunction and and the use of coma, the first line shall be omitted. The second line is a subordinate clause, which means it needs a main clause. The third line is the main clause of the sentence, introducing the subject. The third line per se is already a complete sentence without the fourth line. However, the fourth line serves a different task, and that is to emphasize the object: "the damp souls of housemaids".

Moreover, damp souls is already a negative word choice to show the sadness that the housemaids feel. Still, Eliot seems to emphasize it even more to show an even depressive interpretation of sadness as an objective correlative to poverty. The fourth line serves as an adjective phrase, specifically reduced adjective clause by the usage of present participle of the word sprout as an adjective to the object.

The brown waves of fog toss up to me 
Twisted faces from the bottom of the street

The first line of the second stanza ends with an indirect object me, indicating that the sentence in the first line is losing the direct object and thus cannot be regarded as a complete sentence. The second line fulfills the direct object with the phrase twisted faces and preposition of movement from the bottom of the street.

An aimless smile that hovers in the air

And vanishes along the level of the roofs

An aimless smile is the last noun tossed up by the brown fog to the speaker. However, the enjambement of these last two sentences lacks conjunction. These two lines are subordinate clauses, evident by the usage of that before the verb hovers and the second verb vanishes.

In terms of typography, Morning at the Window is not a typographical poem. The reason is that there is no embedded visual element or shape to emphasize the meaning being delivered by the speaker. Moreover, homolog is the alignment of shapes or lines which further emphasize the same meaning (Riffaterre, 1978). In Morning at the Window, there is no homolog.

\section{Heuristics and Hermeneutics}

The next part of the paper is the interpretation by heuristic and hermeneutic reading. Riffaterre $(1978$, p. 5) proposed that to fully comprehend the semiotics of poetry, there are two levels of reading: heuristics and hermeneutics. Heuristics is the first level of reading where the general meaning of poetry is acquired. Riffaterre (1978) also claimed that the readers' input is their linguistic competence. Linguistic competence is the subconscious knowledge of the grammar of a language that lets a speaker understand the language (Chomsky, 1965). Reading a literary text includes the referential function of language, which is oriented on the context of communication so that ungrammatical sentences within a poem can be perceived. Another input is literary competence (Riffaterre, 1978). This competence helps the readers of a poem to react accordingly to discrepancies. The second level of reading is called hermeneutic or retroactive reading. This level of reading is where the readers interpret the poem the second time in which their initial understandings are examined.

\section{Heuristic Reading}

The poem is opened by the first line, "THEY are rattling breakfast plates in basement kitchens, ". It indicates that the speaker is an observer of the poem and is observing somewhere near the kitchens. He sees them, which probably are servants, cleaning the breakfast plates with noises, which are probably their employers'. It also gives an idea of the time setting. Then, he moves his eyes and gazes the street outside, indicating that he is observing from a house with a window as he can see the trampled edges of the street. Along the street, he is aware of the damp souls of housemaids. He sees the depressive faces on the street, which 
are looking sad and unhappy. He sees them be sprouting despondently, which means that their sadness is growing.

The atmosphere is worse in the second stanza with the appearance of the brown fog, which sets the tone of the atmosphere to be depressive. With the fog, the speaker continues to observe the street. He sees some twisted faces or sad faces on the street passing by. These two first lines also give the readers idea of the exact location of the speaker, located on a window upstairs of a house. He sees a crying woman with muddy skirts passing by, indicating that the street is dirty and wet. He sees an aimless smile of someone on the street without explaining the exact person. The smile is a hopeless smile rather than a happy one, indicating sadness and not happiness. The smile hovers in the air and vanishes along the level of the roofs.

\section{Hermeneutic Reading}

The first stanza of the poem sees the speaker observing the frustrated servants early in the morning, evident by the use of rattling. The first line sets the tone of frustration coming from the servants. In the second line, the speaker moves his sight onto the street. He sees sadness resonating on the faces he sees on the street. The speaker is able to see the sadness that lingers in their minds and souls, which, in stanza 4, keeps getting worse. The faces he sees on the street are housemaids, which are in the same class as the servants in the basement kitchens; the working class. Also, the third and fourth lines indicate sadness and set the tone to become depressive.

Continuing his observation, he sees a brown fog coming. It may be interpreted as a symbolic meaning of brown, which can evoke loneliness, sadness, and emptiness (Cherry, 2020). The color brown can also be interpreted as a literal meaning, indicating that the area is polluted and dirty. Through both metaphorical and literal fog, the speaker sees even more sad faces, using a word twisted to describe them. It still maintains the depressive tone of the poem. In the next line, he sees a crying woman with muddy skirts, indicating that the area is not clean and probably not the nicer part of the town, the area where the working classes typically live. He sees a fake smile from a passer-by. It indicates that some people try to hide their emotions by smiling, which is one of the characteristics of depression.

From both stanzas, we can see the objective correlatives indicating poverty. The tone of frustration, the feeling of sadness, depression, and dirtiness are the object correlatives of poverty. Through these images, the readers can immediately tell that the poem is telling them about poverty. Another thing that can support the images is the objects of observation in the poem. There are servants, housemaids, and a girl with muddy skirts. Those people can be categorized as the working class, who do not live happily because of their economic condition. They have to work every morning as servants or housemaids to serve their employers while receiving improper payments from their works. The time setting may also support the main issue of poverty. Morning at the Window was written in 1914, the first year of The Great War or The First World War. In such a crisis, people would suffer greatly, whether economically or 
psychologically. This condition would be even worse for people living below the poverty line.

\section{Matrix}

The basic meaning of the poem is called Matrix. Matrix is usually based on the readers' perception of how they view the poem, making multi-interpretations possible (Hopkins, 2015). In Morning at the Window, the persona's experience in observing the people around him is the main focus. The paper will use the same method as Diana (2019) in analyzing the poem.

In the first stanza, the persona uses some imageries to convey what he empirically observes.

\section{THEY are rattling breakfast plates in basement kitchens, And along the trampled edges of the street I am aware of the damp souls of housemaids Sprouting despondently at area gates.}

Several words of the first stanza declare the place setting of the poem, although the place where the persona observes is yet to be mentioned. The persona sees them in basement kitchens. He sees the housemaids along the street at area gates. The word breakfast indicates that the time setting of the poem is in the morning. The use of the word rattling to describe what they are doing sets the tone of their frustration. However, the next three lines indicate a different tone, a gloomy or sad tone.

The brown waves of fog toss up to me Twisted faces from the bottom of the street, And tear from a passer-by with muddy skirts An aimless smile that hovers in the air And vanishes along the level of the roofs.

Now, the readers know exactly where the persona observes. From the phrase the bottom of the street, the persona is observing from a window upstairs on the house. The second stanza is also gloomier than the first one. The brown waves of fog set the tone for this stanza. Whether metaphorical or literal, the fog gives a gloomier or more depressive atmosphere. The persona observes even more sad people. He sees twisted faces, tear from a passer-by, and an aimless smile.

From both stanzas, the readers can clearly see how the speaker or persona embedded the objective correlatives of poverty. The speaker uses a high number of words that semantically indicate gloominess to give the reader the images of poverty, in line with Eliot's idea of objective correlative. The readers can also see that not once the speaker even expresses his own emotion; he solely describes what he sees, which is anti-romantic (Shrestha, 2013).

\section{CONCLUSION}

Using Riffaterre's semiotics as the framework to analyze the poem, the paper has come to a conclusion that the representation of the issue in the poem 
is very clear. Poverty in the poem is described through its objective correlatives coined by Eliot. The poem maintains the tone of gloominess or sadness throughout the poem. The use of some words to describe the atmosphere and the people the speaker observes successfully set the tone. It also successfully creates images that correlate with poverty. Based on these, the use of objective correlatives is effective to evoke the readers' emotion towards the main issue of the poem.

\section{REFERENCES}

Abd Allah, M. J. M. (2021). Human Indifference Towards Suffering of Others Depicted in "Morning at the Window" by Yeats \& "Musee des Art" by Auden. International Linguistics Research, 4(2), 55-60. https://doi.org/10.30560/ILR.V4N2P55

Abella, J. (2017). Morning at the Window by T.S. Eliot. Poem Analysis. https://poemanalysis.com/t-s-eliot/morning-at-the-window/

Bundervoet, T. (2013). Poor but Happy? World Bank. https://blogs.worldbank.org/africacan/poor-but-happy

Cherry, K. (2020, June 26). The Color Psychology of Brown. Retrieved January 10, 2021, from https://www.verywellmind.com/the-color-psychology-ofbrown-2795816

Chomsky, N. (1965). Aspects of the Theory of Syntax. Cambridge, MA: MIT Press. Diana, J. (2019). MAKNA PUISI POHON PERADABAN KARYA DINULLAH RAYES KAJIAN SEMIOTIKA RIFFATERRE. Jurnal Pena Indonesia 4 (2): , 173-87.

Eliot, T. S. (1920). Prufrock and Other Observations. From Poems. New York: A.A. Knopf; Bartleby.com, 2011.

Eliot, T. S. (1921). The Sacred Wood. New York: Alfred A. Knopf; Bartleby.com, 1996.

Ending Poverty. (2021). United Nations. https://www.un.org/en/globalissues/ending-poverty

Gweshengwe, B., \& Hassan, N. H. (2020). Defining the Characteristics of Poverty and Their Implications for Poverty Analysis. Cogent Social Sciences, 6(1), 110. https://doi.org/10.1080/23311886.2020.1768669

Hanson, S. (2018). The Happiness Equation: Does Poverty Affect Happiness? Sojourner's Heart, Medium. https://medium.com/sojourners-heart/thehappiness-equation-does-poverty-effect-happiness-ecf12e9f83a

Hopkins, J. F. (2015). Icarus Ignored: Riffaterre and Eagleton on Auden's Musee des Beaux Arts. Semiotica, 185-200.

Howarth, P. (2012). The Cambridge Introduction to Modernist Poetry (1st ed.). Cambridge University Press (CUP).

Kim, Y. (2017). Themes \& Symbols in the Poem “The Waste Land.” Pen and the Pad. https://penandthepad.com/themes-symbols-poem-the-waste-land3697.html

Kuiper, K. (2009). Modernism. Britannica. https://www.britannica.com/art/Modernism-art

Patrick, J. (2017). The Main Characteristics of Modernist Literature. Pen and the Pad. https://penandthepad.com/main-characteristics-modernist-literature8451197.html

Riffaterre, M. (1978). Semiotics of Poetry. Indiana University Press Bloomington. 


\section{Lakon: Jurnal Kajian Sastra dan Budaya Volume 10. No. 2, November 2021}

Sayuti, S. A. (1985). Puisi dan pengajarannya: sebuah pengantar. Semarang: Penerbit IKIP Semarang Press.

Scutti, S. (2018). Less Money can Mean More Contentment, Study Says. CNN. https://edition.cnn.com/2017/12/18/health/poor-rich-happiness-study/index.html

Sharew, B. (2020). The Misconception that Poor People are Happier. Borgen Magazine. https://www.borgenmagazine.com/poor-people-are-happier/

Shrestha, R. (2013, November 25). Morning at the Window by T.S Eliot: Summary and Critical Analysis. Retrieved January 11, 2021, from bachelorandmaster.com/britishandamericanpoetry/morning-at-thewindow.html.

Shook, J. R. (2005). The Dictionary of Modern American Philosophers, Volumes 1, 2, 3 and 4 (1st ed.). Thoemmes Continuum.

Stokes, B. (2007). Happiness is Increasing in Many Countries -- But Why? Pew Research Center. https://www.pewresearch.org/global/2007/07/24/happiness-isincreasing-in-many-countries-but-why/

Tyson, L. (2014). Critical Theory Today: A User-Friendly Guide. New York: Routledge. 